Poznańskie Studia Teologiczne 30(2016), s. 413-431.

doi: $10.14746 /$ pst.2016.30.20

Marek Kluz ${ }^{1}$

Uniwersytet Papieski Jana Pawła II w Krakowie

Wydział Teologiczny Sekcja w Tarnowie

\title{
Kapłan sługą miłosierdzia \\ Refleksja moralno-pastoralna w kontekście Nadzwyczajnego Jubileuszu Mitosierdzia (8 grudnia 2015 - 20 listopada 2016)
}

Ogłoszony przez Ojca Świętego Franciszka bullą Misercicordiae vultus Nadzwyczajny Jubileusz Miłosierdzia staje się okazją do refleksji nad powołaniem kapłańskim w kontekście prawdy o miłosierdziu. Wszyscy kapłani, niezależnie od tego, czy otrzymali specjalną papieską misję w Roku Jubileuszowym, czy nie, są wezwani do tego, aby stać się „misjonarzami miłosierdzia”’. Co więcej, kapłani jako pierwsi są wezwani do tego, aby stać się wiernymi świadkami miłosierdzia. List biskupów polskich do kapłanów na Wielki Czwartek 2016 r. zatytułowany Misjonarze miłosierdzia również wzywa prezbiterów do ubogacenia swojej duchowości w taki sposób, by miłosierdzie stało się ich codziennym stylem życia.

Kapłan żyje autentycznym życiem, kiedy wyznaje i głosi miłosierdzie - najwspanialszy przymiot Stwórcy i Odkupiciela - i kiedy przybliża ludzi do zdrojów miłosierdzia. Życie kapłana jest zatem autentyczne i wiarygodne, gdy czyni z miłosierdzia swoje pełne przekonania przesłanie. Przez wierne urzeczywistnianie tajemnicy miłosierdzia objawionej w Jezusie Chrystusie kapłaństwo staje się „znakiem i narzędziem wewnętrznego zjednoczenia z Bogiem i jedności całego rodzaju ludzkiego"3. Dlatego posłannictwo kapłańskie należy widzieć jako wiel-

\footnotetext{
${ }^{1}$ Marek Kluz ks. dr hab., prof. nadzwyczajny UPJPII, prodziekan Wydziału Teologicznego Sekcja w Tarnowie Uniwersytetu Papieskiego Jana Pawła II w Krakowie. Kierownik Podyplomowych Studiów z Etyki na WTST. Adiunkt z habilitacją przy Katedrze Teologii Moralnej i Duchowości WTST. Autor kilku książek i około 100 artykułów naukowych poświęconych moralności małżeńsko-rodzinnej, etyce cnót, wychowaniu moralnemu, bioetyce, moralności życia społecznego i działalności socjalno-charytatywnej. Adres do korespondencji: pl. Ojca Świętego Jana Pawła II nr 1,33-100 Tarnów, e-mail: mkluz@op.pl, tel. 667419728.

${ }^{2}$ Por. Franciszek, Bulla Misericordiae vultus, Rzym 2015, nr 18.

${ }^{3}$ Sobór Watykański II, Konstytucja dogmatyczna o Kościele Lumen gentium, w: tenże, Konstytucje. Dekrety. Deklaracje, Poznań 1968, nr 1.
} 
ki dar Chrystusa dla dobra całego Kościoła, który „za swój naczelny obowiązek na każdym, a zwłaszcza na współczesnym etapie dziejów uznaje głoszenie i wprowadzanie w życie tajemnicy miłosierdzia"

W tej perspektywie niniejsze refleksje mają na celu - w świetle dokumentów Kościoła, a zwłaszcza pism i wypowiedzi papieży: Jana Pawła II, Benedykta XVI i Franciszka - zachęcić w Roku Świętym do ponownego odnalezienia i ożywienia sensu tożsamości i zasadniczych zadań służby kapłańskiej urzeczywistnianej przede wszystkim w głoszeniu i praktykowaniu miłosierdzia. Niniejsze przemyślenia skierowane są też do tych, którzy chcieliby bliżej zapoznać się z nauczaniem Kościoła na temat służby kapłańskiej. Pozwoli im to lepiej zrozumieć wewnętrzny świat kapłana, tę tajemniczą drogę świętości, po której wraz z ludem podąża za miłosiernym Panem.

\section{Kapłan sługą stołu słowa i sakramentów}

Zadanie objawiania miłosierdzia człowiekowi wyraża się przede wszystkim w podejmowanej przez prezbiterów posłudze słowa i posłudze sakramentalnej. Benedykt XVI w adhortacji apostolskiej Verbum Domini podkreśla to wyraźnie: „Biskupi oraz kapłani zgodnie ze swoją misją, są wezwani jako pierwsi do tego, by ich życie było całkowicie oddane służbie Słowu, do głoszenia Ewangelii i sprawowania sakramentów"s. Podstawowym filarem posługi kapłańskiej, budującym wspólnotę, jest „wykonywanie świętej posługi Ewangelii”, czyli przepowiadanie słowa Bożego. Pierwszeństwo posługi przepowiadania wynika $\mathrm{z}$ tego, że „lud Boży gromadzi się przez słowo Boga żywego". Sobór Watykański II w sposób bardzo świadomy, jednoznaczny i mocny podkreślił to pierwszeństwo ${ }^{8}$, opierając się zarówno na tradycji biblijnej, jak i na doświadczeniu historycznym, które potwierdza, że Kościół jak wspólnota miłości rodzi się ze słowa. Także, „aby być zdolnymi do miłosierdzia - zauważa Ojciec Święty Franciszek - powinniśmy najpierw nastawić się na słuchanie Słowa Bożego". Dlatego homilia czy kazanie powinny być podejmowane zawsze w poczuciu wielkiej odpowiedzialności, ze świadomością, że chodzi o kwestie o największym znaczeniu ${ }^{10}$. Cenne i konkretne wskazówki w tej kwestii dał kaznodziejom papież Franciszek

${ }^{4}$ Jan Paweł II, Encyklika Dives in misericodia, Rzym 1980, nr 14.

${ }^{5}$ Benedykt XVI, Adhortacja apostolska Verbum Domini, Rzym 2010, nr 94.

${ }^{6}$ Sobór Watykański II, Dekret o posłudze i życiu kapłanów Presbyterorum ordinis, w: tenże, Konstytucje..., nr 2.

7 Tamże, $\mathrm{nr} 4$.

${ }^{8}$ Por. Sobór Watykański II, Konstytucja duszpasterska o Kościele w świecie współczesnym Gaudium et spes, w: tenże, Konstytucje..., nr 28.

${ }^{9}$ Franciszek, Bulla Misericordiae vultus..., nr 13.

${ }^{10}$ Por. Benedykt XVI, Adhortacja apostolska Verbum Domini..., nr 59. 
w adhortacji apostolskiej Evangelii gaudium ${ }^{11}$. W jednym z numerów tejże adhortacji podkreśla, że „homilia stanowi kryterium oceny bliskości i zdolności spotkania pasterza ze swoim ludem"12. Homilia nie może być zatem spektaklem rozrywkowym, nie może też kierować się logiką przekazów medialnych, ale ma wzbudzać zapał i nadawać sens celebracji liturgicznej ${ }^{13}$. „Stąd powinna być krótka i powinna unikać sprawiania wrażenia, że jest jakąś konferencją czy lekcją"14.

W budowaniu chrześcijańskiej wspólnoty prezbiterzy nigdy nie służą jakiejś ideologii czy grupie ludzi, ale jako heroldowie Ewangelii i pasterze Kościoła trudzą się nad osiągnięciem duchowego wzrostu Ciała Chrystusowego" "15. Głoszenie homilii lub kazania nie może więc sprowadzać się do przekazywania własnych myśli i wyjaśnień o charakterze psychologicznym czy socjologicznym. Prezbiter nie powinien również zbytnio ulegać urokowi retoryki. Jego orędzie nie może być jednak abstrakcyjne i odległe od życia ludzi, przeciwnie, powinno mieć bezpośrednie odniesienie do sensu życia człowieka i podejmować najbardziej aktualne zagadnienia, które stają przed jego sumieniem. W tej perspektywie słusznie zauważa papież Franciszek, że

kaznodzieja powinien słuchać ludu, aby odkryć to, co wierni powinni usłyszeć. Kaznodzieja jest człowiekiem kontemplującym Słowo, a także kontemplującym lud [...]. Chodzi o powiązanie przesłania tekstu biblijnego z ludzką sytuacja, z tym, czym ludzie żyją, z doświadczeniem potrzebującym światła Słowa. Ta troska nie odpowiada postawie oportunistycznej lub dyplomatycznej, ale jest głęboko religijna i duszpasterska. W gruncie rzeczy jest ,wrażliwością duchową, aby w wydarzeniach odczytywać przesłanie Boże"16.

Sobór Watykański II mówi wyraźnie, że jedną z istotnych form przepowiadania jest badanie ,problemów swojego czasu w świetle Chrystusowym, odnosząc niezmienną prawdę Ewangelii do konkretnych warunków życia"17. Głosząc z mocą w imieniu Chrystusa słowo Boże, wobec rozmaitych problemów doczesnego życia, kapłan może wnieść twórczy wkład w ich rozwiązywanie przyczyniając się w ten sposób do budowania wspólnoty Kościoła.

Posługa słowa, właściwie pojęta - prowadzi do sakramentów i do życia chrześcijańskiego. „Celem sakramentów jest uświęcenie człowieka, budowanie

${ }^{11}$ Por. szerzej: Franciszek, Adhortacja apostolska Evangelii gaudium, Rzym 2013, nr 135-159.

Por. także: Benedykt XVI, Adhortacja apostolska Sacramentum caritatis, Rzym 2007, nr 46.

${ }^{12}$ Tamże, nr 135.

${ }^{13}$ Por. tamże, nr 138 .

${ }^{14}$ Tamże.

${ }^{15}$ Sobór Watykański II, Dekret o posłudze i życiu kapłanów Presbyterorum ordinis, w: tenże, Konstytucje..., nr 6.

${ }^{16}$ Franciszek, Adhortacja apostolska Evangelii gaudium..., nr 154.

${ }^{17}$ Sobór Watykański II, Dekret o posłudze i życiu kapłanów Presbyterorum ordinis, w: tenże, Konstytucje..., nr 4. 
mistycznego Ciała Chrystusa oraz oddawanie kultu Bogu"18. Szczytem ewangelizacji i sakramentów jest Eucharystia. Kwestia ta została syntetycznie i głęboko wyrażona w nauczaniu soborowym: „Pozostałe zaś sakramenty, tak jak i wszystkie kościelne posługi i dzieła apostolstwa, wiążą się ze świętą Eucharystią i ku niej zmierzają. W najświętszej Eucharystii zawiera się bowiem całe dobro duchowe Kościoła"19.

W przeszłości kościół parafialny stanowił centrum, wokół którego skupiało się życie ludzi; dzwony wyznaczały rytm pracy w ciagu dnia; świętowanie było świętowaniem przede wszystkim w kościele i wokół kościoła. Sekularyzacja dokonała rozbicia tak ukształtowanej struktury życia ludzkiego. Jednak dla wiernych kościół stanowi nadal centrum życia wiary. Uczta eucharystyczna stanowi centrum zgromadzenia wiernych, „centrum wypełnione miłością i niewyczerpanym życiem" ${ }^{20}$. W tej perspektywie dobra celebracja Eucharystii przez kapłana, stanowi pierwszą i ważną katechezę o Najświętszej Ofierze. W Eucharystii wierni uczą się „dostrzegać głębię rzeczywistości”" jego życia, swojej pobożności i swojej moralności. Natomiast niedbalstwo, pośpiech, powierzchowność i nieporządek w liturgii eucharystycznej, osłabia jej wpływ na wzrost wiary i rozwój kościelnej komunii ${ }^{22}$. W tej perspektywie słuszna jest rada papieża Benedykta skierowana do kapłanów w adhortacji Sacramentum caritatis: „Polecam zatem duchownym, by zawsze pogłębiali świadomość własnej posługi eucharystycznej jako pokornej służby wobec Chrystusa i Jego Kościoła. Kapłaństwo, jak mawiał św. Augustyn - jest amoris officium - urzędem dobrego pasterza, który ofiaruje swoje życia za owce (por. J 10, 14-15)"’23.

Obowiązkiem duszpasterzy jest takie sprawowanie Eucharystii, aby doświadczenie komunii wyniesione ze świątyni, znajdowało swoje potwierdzenie i dopełnienie w życiu parafii ${ }^{24}$. Istnieje zatem silna potrzeba wychowania uczestników Eucharystii, do poczucia odpowiedzialności za każdego człowieka zwłaszcza ubogiego, gdyż nie ma gorszego świadectwa o parafii, jak uśmiercona posługa charytatywna. Klucz do wszelkiej dobroczynności tkwi bowiem w parafii. Urzeczywistnianie Kościoła dokonuje się w jego najbardziej skondensowanym wydarzeniu, jakim jest Eucharystia, która jest przygotowana i interpretowana przez

\footnotetext{
${ }^{18}$ Sobór Watykański II, Konstytucja o liturgii świętej Sacrosanctum concilium, w: tenże, Konstytucje..., nr 59.

${ }^{19}$ Sobór Watykański II, Dekret o posłudze i życiu kapłanów Presbyterorum ordinis, w: tenże, Konstytucje..., nr 5.

${ }^{20}$ Franciszek, Encyklika Laudato si', Rzym 2015, nr 236.

${ }^{21}$ Por. Franciszek, Encyklika Lumen fidei, Rzym 2013, nr 44.

22 Por. A. Kokoszka, Rozpalić kapłański charyzmat, w: W trzecie tysiaclecie. Komentarz pastoralny do dokumentów II Polskiego Synodu Plenarnego, red. W. Lechowicz, Tarnów 2002, s. 132.

${ }^{23}$ Benedykt XVI, Adhortacja apostolska Sacramentum caritatis..., nr 23.

${ }^{24}$ Por. W. Przygoda, Postuga charytatywna Kościoła w Polsce. Studium teologiczno-pastoralne, Lublin 2004, s. 146.
} 
rozważanie słowa Bożego, natomiast potwierdzona w życiu społecznym przez miłość i dobroczynność ${ }^{25}$.

Zdaniem papieża Franciszka ,szczególne ważne jest uczestnictwo w niedzielnej Eucharystii”26. To w niej ma swoje korzenie duch braterskiej wspólnoty, dlatego od niej trzeba rozpoczać wszelkie wychowanie do ducha wspólnoty. To z Eucharystii wypływa zobowiązanie do miłości braci i służby tym, za których Chrystus złożył swoje życie w ofierze ${ }^{27}$.

Biskup ma obowiązek zatroszczyć się o godne sprawowanie Eucharystii w powierzonej mu diecezji i o to, aby jak największa liczba wiernych mogła przyjmować Ciało i Krew Chrystusa. To zobowiązanie wymaga umożliwienia uczestnictwa we Mszy świętej ludziom starszym i chorym w ich domach lub szpitalach. Obowiązkiem biskupa jest zapewnienie odpowiednio przygotowanych kapelanów szpitalnych i więziennych, gdyż niezbędnym ze strony kościelnej jest odpowiednie duszpasterstwo w różnych miejscach cierpienia i przeżywania choroby i odosobnienia ${ }^{28}$.

Wśród osób, które doświadczają wielkich trudności, a tym samym stanowią szczególny podmiot chrześcijańskich dzieł miłości, można znaleźć i tych, którzy znajdują się w sytuacji ubóstwa moralnego, czyli w sytuacji grzechu ${ }^{29}$. Szczególnym zadaniem prezbiterów jest w tym względzie podejmowanie wielkodusznej posługi w konfesjonale, gdzie „,człowiek może w szczególny sposób doświadczyć miłosierdzia, czyli tej miłości, która jest potężniejsza niż grzech" ${ }^{30}$. Wytrwała posługa w konfesjonale - zadaniem Jana Pawła II - ,jest to niewątpliwie najtrudniejsza i najbardziej delikatna, męcząca i wyczerpująca, ale też najpiękniejsza i przynosząca radość posługa kapłańska"31. Dlatego Papież niestrudzenie nawoływał kapłanów do wiernego i gorliwego sprawowania sakramentu pokuty. Podobnie to czyni Ojciec Święty Franciszek w bulli Misericordiae vultus ogłaszającej Nadzwyczajny Jubileusz Miłosierdzia:

Niech nie zmęczy spowiedników to, że będą musieli wyjść do drugiego syna, który pozostał na zewnątrz i jest niezdolny do radości, aby wytłumaczyć mu, że jego ostry osąd jest niesprawiedliwy i nie ma sensu w obliczu miłosierdzia Ojca, które nie zna

${ }^{25}$ Por. Benedykt XVI, Adhortacja apostolska Verbum Domini, Rzym 2010, nr 106. Por. także: Benedykt XVI, Adhortacja apostolska Sacramentum caritatis..., nr 88-89.

${ }^{26}$ Franciszek, Encyklika Laudato si'..., nr 237. Por. także: Benedykt XVI, Adhortacja apostolska Sacramentum caritatis..., nr 73.

${ }^{27}$ Por. Jan Paweł II, Encyklika Dives in misericodia..., nr 13. Por. także: Benedykt XVI, Adhortacja apostolska Sacramentum caritatis..., nr 88.

${ }^{28}$ Por. Jan Paweł II, Adhortacja apostolska Ecclesia in Europa, Rzym 2003, nr 88. Por. także: Benedykt XVI, Adhortacja apostolska Sacramentum caritatis..., nr 58-59.

${ }^{29}$ Por. M. F. Kowalska, Dzienniczek, Warszawa 1993, nr 72, s. 45.

${ }^{30}$ Jan Paweł II, Encyklika Dives in misericodia..., nr 13.

${ }^{31}$ Por. Jan Paweł II, Adhortacja apostolska Reconciliatio et paenitentia, Rzym 1984, nr 29. 
granic. [...]. Spowiednicy są wezwani do tego, aby byli zawsze i wszędzie, w każdej sytuacji i pomimo wszystko, znakiem prymatu miłosierdzia ${ }^{32}$.

Nie można w tym miejscu pominąć także drugiego spośród sakramentów uzdrowienia, jakim jest namaszczenie chorych. Jego sprawowanie wpisuje się głęboko w posługę wobec chorych i umierających. Papież Benedykt XVI zauważa ponadto, że „uwaga i troska duszpasterska wobec tych, którzy doświadczają choroby, przynosi korzyść duchową całej wspólnocie"33. Nowa nazwa sakramentu podpowiada nową koncepcję samego duszpasterstwa chorych i nie chodzi tu wcale o nieistotne zmiany, lecz o radykalną przebudowę świadomości wiernych w odniesieniu do podmiotu sakramentu (komu należy go udzielać) i czasu jego przyjmowania $^{34}$. Ta zmiana świadomości powinna dotyczyć także samych szafarzy, czyli biskupów i prezbiterów, by zawsze chętnie spieszyli z posługą wobec chorych i udzielali im sakramentalnego wsparcia ${ }^{35}$.

\section{Kapłan człowiekiem milości i przyjacielem ubogich}

Papież Benedykt XVI w encyklice Deus caritas est podkreśla, że

wewnętrzna natura Kościoła wyraża się w troistym zadaniu: głoszenie Słowa Bożego (kerygma-martyria), sprawowanie sakramentów (leiturgia), posługa miłości (diaconia). Są to zadania ściśle ze sobą związane i nie mogą być od siebie oddzielone. Caritas nie jest dla Kościoła rodzajem opieki społecznej, którą można by powierzyć komu innemu, ale należy do jego natury, jest niezbywalnym wyrazem jego istoty ${ }^{36}$.

Nauczanie Kościoła szczególnie mocno akcentuje znaczenie realizacji przykazania miłości bliźniego w posłudze prezbiterów. Budowanie kościelnej wspólnoty urzeczywistnia się przede wszystkim, w miłości i głębokim szacunku prezbitera wobec każdego człowieka. Kapłan - niejako ex officio - powinien zawsze odznaczać się należytym szacunkiem, wrażliwością, współczuciem i wielkodusznością ${ }^{37}$. Każdy prezbiter powinien starać się na wzór Chrystusa odtworzyć w swoim życiu miłosierną miłość do owczarni. Jan Paweł II uczył, że kapłaństwo wymaga wyrzeczenia się osobistych ambicji i chęci panowania nad innymi. W żaden sposób nie licuje z kapłaństwem postawa wywyższania się i autokratyzmu.

\footnotetext{
${ }^{32}$ Franciszek, Bulla Misericordiae vultus..., nr 17.

${ }^{33}$ Benedykt XVI, Adhortacja apostolska Sacramentum caritatis..., nr 22.

${ }^{34}$ Por. A. Bartoszek, Człowiek w obliczu cierpienia i umierania. Moralne aspekty opieki paliatywnej, Katowice 2000, s. 259-260.

${ }^{35}$ Por. Benedykt XVI, Adhortacja apostolska Verbum Domini..., nr 61, 106.

${ }^{36}$ Benedykt XVI, Encyklika Deus caritas est, Rzym 2005, nr 25.

${ }^{37}$ Por. Sobór Watykański II, Dekret o posłudze i życiu kapłanów Presbyterorum ordinis, w: tenże, Konstytucje..., nr 9.
} 
Amor pastoralis przejawia się w życiu kapłana w postawie współczucia okazywanego przygnębionym, zainteresowaniu problemami chorych i cierpiących, w karmieniu głodnych, w trosce o ubogich, sieroty i wdowy, a także w postawie miłosierdzia okazywanej grzesznikom. Dla realizacji wymogów miłości pasterskiej niezbędne są cierpliwość, gotowość do szybkiego przebaczenia, uprzejmość, ofiarność w udzielaniu pomocy oraz postawa służby, która powinna być wolną od eksponowania osobistych zasług ${ }^{38}$. Autentyczny sługa Kościoła to ten, który uzyskał wolność tracenia własnego czasu dla potrzeb innych, a jako swój przywilej traktuje umywanie nóg najbiedniejszym. „Kościół - pisze Benedykt XVI w Verbum Domini - nie może zawieść ubogich: «Duszpasterze winni ich słuchać, uczyć się od nich, prowadzić ich w wierze i motywować do tego, by byli czynnymi twórcami własnej historii»" ${ }^{\prime 39}$.

Kapłan ma być człowiekiem miłosiernej miłości, powołanym do wychowywania innych zgodnie z pozostawionym przez Chrystusa wzorem i nowym przykazaniem miłości braterskiej. Aby sprostać temu zadaniu kapłan, sam musi przyzwolić, aby Duch Święty nieustannie wychowywał go do miłości Chrystusa. Stąd też już samo przygotowanie do kapłaństwa nie może pomijać solidnej formacji do praktykowania miłości miłosiernej, zwłaszcza miłości preferencyjnej do «ubogich», w których wiara odkrywa obecność Jezusa (por. Mt 25,40), a także miłości miłosiernej do grzeszników ${ }^{40}$. W duszpasterstwie powołaniowym trzeba dokonać przejścia od „duszpasterstwa propagandy” do „duszpasterstwa służby” szczególnie w stosunku do najbiedniejszych i potrzebujących ${ }^{41}$.

Wśród zadań prezbitera należy wyliczyć obowiązek ukazywania znaczenia miłości w życiu społecznym. Wyraża się to w inspirowaniu dzieł miłosierdzia oraz organizowaniu pomocy charytatywnej wśród potrzebujących. Każda wspólnota winna być otwarta na służbę ubogim, a postawa pokory i wyrzeczenia, towarzysząca opcji na rzecz ubogich, ukazuje światu bardziej autentyczne oblicze chrześcijańskiej wspólnoty, której wszyscy członkowie spieszą z pomocą potrzebującym i cierpiącym braciom. Kształtuje się tym samym pewne środowisko szczególnie sprzyjające przyjęciu daru powołania.

Drogą do rozwijania miłości miłosiernej jest też zaangażowanie się prezbitera w rozwijanie wolontariatu. Wychowanie do wiary polega przede wszystkim na rozwijaniu tego, co w człowieku dobre i wartościowe. Wielką zatem szansą

\footnotetext{
${ }^{38}$ Por. Jan Paweł II, Adhortacja apostolska Pastores dabo vobis, Rzym 1992, nr 23. Por. także: W. Słomka, Duchowość kapłańska, Lublin 1996, s. 219-221.

${ }^{39}$ Benedykt XVI, Adhortacja apostolska Verbum Domini..., nr 107. Por. także: Franciszek, Adhortacja apostolska Evangelii gaudium..., nr 186.

${ }^{40}$ Por. S. Mojek, Formacja do czynnej miłości miłosiernej $w$ duszpasterstwie parafialnym, „Roczniki Teologiczne” 49(2002), z. 3, s. 115-133. Por. także: S. Mojek, Preferencyjna miłość do ubogich w duszpasterstwie parafialnym, „Roczniki Teologiczne” 48(2001), z. 3, s. 113-131.

${ }^{41}$ Por. Sobór Watykański II, Konstytucja dogmatyczna o Kościele Lumen gentium, w: tenże, Konstytucje..., nr 26.
} 
wychowawczą jest zaangażowanie się kapłana w rozwój wolontariatu, który ma być inspirowany duchem ewangelicznym. Wolontariusze wspomagają działania, które czynią ten świat lepszym miejscem do życia, zwłaszcza dla najsłabszych. We współczesnym świecie nastawionym na zysk i konsumpcję inicjatywy podejmowane $\mathrm{w}$ ramach akcji wolontariatu pomagają uwrażliwić się na ludzki los i cierpienie ${ }^{42}$. Podkreślił to papież Benedykt XVI w encyklice Deus caritas est: „Ważnym zjawiskiem w naszych czasach jest powstanie i rozszerzanie się różnych form wolontariatu, które wyrażają się w wielorakich posługach. Pragnę wyrazić moje uznanie i wdzięczność wszystkim, którzy w jakikolwiek sposób uczestniczą w tej działalności. To szerokie zaangażowanie stanowi [...] szkołę życia i uczy solidarności, gotowości do dawania nie tylko czegoś, ale siebie samych" ${ }^{33}$.

Kodeks prawa kanonicznego przypomina ponadto kapłanom, że wszelkie podejmowane przez nich akcje charytatywne powinni wspierać ze swoich dochodów. Kodeks stwierdza: „Duchowni powinni prowadzić życie proste i powstrzymywać się od wszystkiego, co trąci próżnością”"4. I dalej: „z dóbr, które im przypadły z racji wykonywania kościelnego urzędu, to, co im zbywa po zapewnieniu godziwego utrzymania i wypełnieniu wszystkich obowiązków własnego stanu, niech zechcą przeznaczyć na dobro Kościoła i dzieła miłości”"45. Jan Paweł II także wielokrotnie podkreślał, że urząd kościelny nie może być dla prezbiterów ani też dla biskupów - okazją do osobistego wzbogacenia się, czy też czerpania korzyści dla rodziny. Choć ewangeliczną prawdą jest, że „godny jest robotnik swojej zapłaty" (por. Łk 10,7) i że Pan postanowił, ażeby z Ewangelii żyli ci, którzy głoszą Ewangelię (por. 1 Kor 9,14), to niemniej prawdą jest także, iż „,prawa Apostoła nie powinno się absolutnie mylić z jakąkolwiek próbą uzależnienia służby Ewangelii i Kościołowi od korzyści i zysków, które można z niej czerpać. Jedynie ubóstwo jest gwarancją, że kapłan będzie gotowy udać się tam, gdzie jego praca jest bardziej pożyteczna i pilna, także kosztem wyrzeczeń osobistych" ${ }^{46}$. Pokusa grzesznego bogacenia się może stać się osobistą tragedią kapłana, gdyż zapatrzenie się $\mathrm{w}$ dobra materialne nie pozwala w należyty sposób realizować zadania sługi Chrystusa ubogiego ${ }^{47}$.

Kapłan, który jest osobiście włączony w życie powierzonej mu wspólnoty, a przez to i za nią odpowiedzialny, powinien dawać świadectwo całkowitej przejrzystości w rozporządzaniu dobrami materialnymi ${ }^{48}$. Nie powinien ich nigdy trak-

${ }^{42}$ Por. S. Mojek, Wolontariat chrześcijański wyrazem czynnej miłości bliźniego, „Roczniki Teologiczne" 47(2000), z. 3, s. 189-207.

${ }_{43}$ Benedykt XVI, Encyklika Deus caritas est..., nr 30.

${ }^{44}$ Kodeks prawa kanonicznego, Poznań 1984, kan. 282, par. 1.

${ }^{45}$ Tamże, kan. 282, par. 2.

${ }^{46}$ Jan Paweł II, Adhortacja apostolska Pastores dabo vobis..., nr 30.

${ }^{47}$ Por. Z.J. Kijas, Nowy kapłan na nowe czasy. Rozważania na temat duchowości kapłańskiej, Kraków 2002, s. 121.

${ }^{48}$ Por. Jan Paweł II, Encyklika Dives in misericodia..., nr 14. 
tować, jakby były one jego własnym majątkiem, ale jako rzecz, z której musi zdać sprawę Bogu i braciom, przede wszystkim ubogim. Kapłan powinien także rozwijać w sobie świadomość tego, że jest członkiem prezbiterium Kościoła partykularnego i dlatego powinien $\mathrm{z}$ większym jeszcze zaangażowaniem zabiegać o bardziej sprawiedliwy podział dóbr między współbraćmi, jak i o wspólne używanie pewnych dóbr ${ }^{49}$. Bardzo rzadko zdarza się, że sytuacja wymaga pewnego nadzwyczajnego zaangażowania. Codziennością z kolei są sytuacje, w których chodzi o miłość prostą, zwyczajną i może trudną do zauważenia, ale stałą i wielkoduszną, zwłaszcza wobec chorych i umierających.

Wolność wewnętrzna, którą daje kapłanowi ubóstwo ewangeliczne, sprawia, że potrafi on stanąć u boku biednych, okazać solidarność z ich wysiłkami na rzecz ustanowienia bardziej sprawiedliwego społeczeństwa, być wrażliwszym i lepiej rozumieć i rozróżniać zjawiska związane z ekonomicznym i społecznym aspektem życia, popierać opcję preferencyjną na rzecz ubogich. To popieranie opcji na rzecz ubogich w życiu kapłana ani nie wyklucza nikogo z głoszenia jemu Dobrej Nowiny, ani też nikogo nie pozbawia daru zbawienia, ale każe pochylać się nad najmniejszymi braćmi, grzesznikami, nad wszelkiego rodzaju ludźmi zepchniętymi na margines, zgodnie ze wzorem, jaki dał Jezus, wypełniając swoje prorockie i kapłańskie posłannictwo (por. Łk 4,18) ${ }^{50}$.

Kodeks prawa kanonicznego, omawiając obowiązki proboszcza, jego szczególnej opiece powierza „biednych, cierpiących, samotnych, wygnańców oraz przeżywających szczególne trudności" ${ }^{51}$. Ta troska o potrzebujących nie może iść w parze z bogactwem i zachłannością kapłanów. Takie postawy szkodzą budowaniu prawdziwej miłości. Dobrowolne ubóstwo i skromność kapłańskiego życia są natomiast najlepszymi sprzymierzeńcami budujących wspólnotę miłości. Mimo iż prezbiterzy diecezjalni nie zobowiązują się do zachowania ubóstwa na wzór życia zakonnego, to jednak ich skromne życie i postawa służby wskazują na więź z Chrystusem, który ogołocił samego siebie i przyjął postać sługi (por. Flp 2,7) ${ }^{52}$. Jezus Chrystus, który na Krzyżu objawia doskonałość swojej miłości pasterskiej poprzez bezgraniczne ogołocenie siebie zarówno w wymiarze zewnętrznym, jak i wewnętrznym, jest wzorem i źródłem cnót posłuszeństwa, czystości i ubóstwa. Kapłan jest wezwany, „by przez praktykę tych cnót wyrazić swą pasterską miłość do braci. Zgodnie z tym, co Paweł pisze do chrześcijan z Filippi, kapłan winien mieć «te same dążenia» co Jezus, ogołacając się z własnego «ja», by odnaleźć w miłości posłusznej, czystej i ubogiej główną drogę do zjednoczenia z Bogiem i jedności z braćmi (por. Flp 2,5)" ${ }^{\prime 3}$.

${ }^{49}$ Por. Jan Paweł II, Adhortacja apostolska Pastores dabo vobis..., nr 30. Por. także: J. Międzybrodzki, Duchowość kapłana w nauczaniu Jana Pawła II, Katowice 2007, s. 474-475.

${ }^{50}$ Por. Jan Paweł II, Adhortacja apostolska Pastores dabo vobis..., nr 30.

${ }^{51}$ Kodeks prawa kanonicznego..., kan. 529, par. 1.

${ }^{52}$ Por. W. Przygoda, Postuga charytatywna Kościoła w Polsce..., s. 147.

${ }^{53}$ Jan Paweł II, Adhortacja apostolska Pastores dabo vobis..., nr 30. 
Kapłan ubogi i rozumiejący ideę ubóstwa ewangelicznego potrafi postawić sobie pytanie, dotyczące sytuacji bytowej ludzi biednych i skrzywdzonych przez los, którzy żyją w jego parafii. Ważne jest, aby ubodzy zajmowali poczesne miejsce we wspólnocie parafialnej. „Ubodzy są bowiem - jak stwierdził Ojciec Święty Franciszek - uprzywilejowani dla Bożego miłosierdzia"54. Dlatego kapłan winien stać po stronie ludzi ubogich, nie zabiegając jedynie o względy bogatych i żyjąc jak bogaci55. Ubóstwo kapłana ułatwia mu miłość bliźnich i prowadzi do solidarności z biednymi, jak i do służenia im w potrzebie.

Dyrektorium o postudze i życiu prezbiterów wzywa kapłanów do wyeliminowania wszelkich oznak próżności i luksusu, zwłaszcza jeśli chodzi o mieszkanie i jego wyposażenie, środki transportu, czy sposób spędzania wolnego czasu albo wakacji. Kapłan powinien być przyjacielem ubogich, powinien „okazywać im szczególnie delikatne zainteresowanie swojej miłości duszpasterskiej, z opcją preferencyjną dla wszystkich starych i nowych form ubóstwa tragicznie obecnych w świecie" ${ }^{56}$. Z kolei w encyklice Sollicitudo rei socialis Jan Paweł II wezwał kapłanów, aby nie przedkładali bogatego wystroju świątyń, bogatych szat i drogocennych paramentów liturgicznych przeznaczonych do kultu Bożego nad zaspokajanie fundamentalnych potrzeb ludzkich. Stwierdza on nawet, że niejednokrotnie „może okazać się konieczne sprzedanie tych dóbr, aby dać chleb, napój, odzież i dom temu, kto jest ich pozbawiony"57.

Nade wszystko jednak prezbiter winien cechować się bezinteresownością i dystansem wobec pieniędzy, odrzucaniem zachłannego pragnienia dóbr doczesnych, prostym stylem życia i rezygnacją ze wszystkiego, co jest lub wydaje się być luksusem. Trzeba pamiętać także, że kapłani są przez Chrystusa powołani do głoszenia Ewangelii ubogim zgodnie z przykładem, jaki On pozostawił, prezbiterzy, jak i biskupi winni unikać wszystkiego, co mogłoby w jakikolwiek sposób zrazić ubogich. Ożywiając natomiast w sobie ducha ewangelicznego ubóstwa, będą mogli dać dowód preferencyjnej opcji na rzecz ubogich, wyrażając ją konkretnie przez dzielenie się dobrami, przez indywidualne i społeczne dzieła pomocy, także materialnej, niesionej ubogim. Takie świadectwo życia ubogiego i z ubogimi składa dzisiaj wielu kapłanów. Stanowi ono wielki płomień miłości w życiu duchowieństwa i Kościoła. Jeśli w przeszłości można było zaliczyć duchownych w niektórych krajach do kategorii ludzi bogatych, dziś wraz z całym Kościołem uważają oni za zaszczyt to, że

\footnotetext{
${ }^{54}$ Franciszek, Bulla Misericordiae vultus..., nr 15.

${ }_{55}$ Por. J. Baniak, Wierność powołaniu, a kryzys tożsamości kapłańskiej. Studium socjologiczne na przykładzie Kościoła w Polsce, Poznań 2000, s. 196.

${ }^{56}$ Kongregacja do spraw Duchowieństwa, Dyrektorium o postudze i życiu prezbiterów, Kraków 2013, nr 83.

${ }^{57}$ Jan Paweł II, Encyklika Sollicitudo rei socialis, Rzym 1987, nr 31. Por. także: Jan Paweł II, Dar i tajemnica, Kraków 1996, s. 87.
} 
znajdują się w pierwszym szeregu ,nowych ubogich”. Jest to wielki postęp w naśladowaniu Chrystusa drogą Ewangelii.

Nie można bowiem zapominać także o prorockim wymiarze kapłańskiego ubóstwa, które jest szczególnie potrzebne w społeczeństwach zamożnych i konsumpcyjnych. Prawdziwie ubogi kapłan jest niewątpliwie „konkretnym znakiem odcięcia się, odrzucenia, a nie poddania się presji współczesnego świata, który pokłada całą swoją nadzieję w pieniądzu i w bezpieczeństwie materialnym"s8.

\section{Kapłan sługą wspólnoty parafialnej}

Kapłani posiadający święcenia reprezentują Chrystusa, który jest Głową Kościoła i powołani są do służby całemu Ludowi Bożemu na wzór Dobrego Pasterza. Działają w imieniu Chrystusa i Kościoła ${ }^{59}$. Ta władza reprezentowania Chrystusa wypływa z charakteru sakramentalnego. W jednym z listów do kapłanów na Wielki Czwartek papież Jan Paweł II pisał:

Jest więc nasze kapłaństwo sakramentalne - kapłaństwem hierarchicznym i zarazem „służebnym”. Stanowi szczególne misterium - jest „posługą” względem wspólnoty wierzących. Nie pochodzi jednakże od tej wspólnoty, z jej jak gdyby wezwania i ,delegacji”. Jest darem dla tej wspólnoty, który pochodzi od samego Chrystusa, z pełni Jego własnego Kapłaństwa ${ }^{60}$.

Tak więc sakrament kapłaństwa ma ze swej natury charakter służebny ${ }^{61}$. Na wzór Chrystusa kapłan musi być żertwą ofiarną wydaną za bliźnich. Sakramentu święceń bowiem nie przyjął dla siebie. Podkreślił to papież Franciszek w bulli Misericordiae vultus: „Nikt z nas nie jest panem sakramentu, ale wiernym sługą" ${ }^{92}$. Kapłan wzięty spośród ludzi, dla ludzi też został ustanowiony, po to, by sam kształtowany przez łaskę - udzielał je innym: leczył zranione serca, ukazywał drogę wyzwolenia od zła, dotykał miłością. Kapłaństwo oznacza więc służ-

58 Jan Paweł II, Adhortacja apostolska Pastores dabo vobis..., nr 30.

${ }_{59}$ Por. Jan Paweł II, Adhortacja apostolska Christifideles laici, Rzym 1988, nr 22. Por. także: tenże, Adhortacja apostolska Pastores dabo vobis..., nr 21, 22.

${ }^{60}$ Jan Paweł II, List do kapłanów na Wielki Czwartek „,Kapłaństwo stużebne”, w: Listy Ojca Świętego Jana Pawła II do wszystkich kapłanów Kościoła Na Wielki Czwartek (1979-1997), red. D. Greggio, Kraków 1998, s. 16-17.

${ }^{61}$ Szeroko na temat służebnego charakteru kapłaństwa pisał Jan Paweł II do kapłanów na Wielki Czwartek. Por. tenże, Listy Ojca Świętego Jana Pawła II do wszystkich kapłanów Kościoła na Wielki Czwartek (1979-1997), Kraków 1998, s. 11-249. Por. także: J. Nagórny, Kapłan - stuga Nowego Przymierza, „Roczniki Teologiczno-Kanoniczne” 1986, z. 3, s. 55-71; W. Słomka, Natura i misja służebnego kapłaństwa, w: Źródło postaw i życia chrześcijańskiego, red. W. Słomka, Lublin 1996, s. 266-277; J. Misiurek, Nauka Soboru Watykańskiego II o prezbiteracie, w: Kapłan pośród ludu kapłańskiego. Homo meditans XIV, red. W. Słomka, J. Misiurek, Lublin 1993, s. 76-82.

${ }^{62}$ Franciszek, Bulla Misericordiae vultus..., nr 17. 
bę każdemu konkretnemu człowiekowi. Ta służba, można powiedzieć, jest racją bytu życia kapłańskiego, ona nadaje mu sens.

Trzeba ponadto zauważyć, że tylko wówczas naprawdę można służyć ludziom, gdy jest się blisko nich i ich spraw: osobistych, rodzinnych, zawodowych, społecznych. Chodzi jednak o obecność „kapłańską”, a więc otwierającą się w każdej sytuacji na obecność Boga żywego i prowadzącą do Niego, pokazująca zawsze perspektywę zbawienia. Aby tak się działo, ksiądz nie może patrzeć na człowieka inaczej jak tylko z miłością, która jest darem i zobowiązaniem. „Jako dar, którą wszyscy otrzymali - uświadamia papież Benedykt w encyklice Caritas in veritate - miłość [...] stanowi siłę tworzącą wspólnotę, jednoczy ludzi w taki sposób, że nie ma barier ani granic" ${ }^{33}$. Kapłan powinien odgrywać rolę znaku i świadka Bożej miłości miłosiernej. Ma stawać się powiernikiem ludzi świeckich w sprawach o charakterze zasadniczym. Jego przyjaźń z Chrystusem w sposób naturalny winna się zatem przekładać na konkretną służbę.

W jakich konkretnych zadaniach powinna się wyrażać służba kapłańska wobec wspólnoty wierzących? Doniosłe znaczenie dla budowania wspólnoty ma szeroko pojęta katecheza. Szczególnie należy tu podkreślić wartość katechezy parafialnej, która stanowi dopełnienie szkolnej katechezy. W ramach tej katechezy dzieci i młodzież są przygotowywane do sakramentów wtajemniczenia chrześcijańskiego. Nie musi się ona jednak ograniczać tylko do tych grup. W budowaniu wspólnoty parafialnej należy zatroszczyć się o organizację katechezy dorosłych tam, gdzie tego brak, oraz wspierać środowiska, które takie nauczanie już podejmują. Katecheza ta powinna być oparta na Piśmie Świętym. Nawołuje do tego wyraźnie papież Franciszek w adhortacji Evangelii gaudium: „Istotne jest, aby objawione Słowo radykalnie ubogacało katechezę i wszystkie wysiłki podejmowane w celu przekazania wiary" ${ }^{\prime 64}$. Ważną rzeczą jest też zaznajamianie się z nauczaniem Magisterium Kościoła. Pomocą może być tutaj Katechizm Kościoła katolickiego i Kompendium nauki społecznej Kościoła, różne pomoce dydaktyczne i środki przekazu. Cenną pomocą w katechezie dorosłych może być także obfite nauczanie św. Jana Pawła II, Benedykta XVI i Franciszka. Chodzi bowiem o to, aby katechizowani, w sposób dostosowany do ich możliwości i warunków życia, byli w stanie wniknąć w doktrynę chrześcijańską i stosować ją w życiu rodzinnym i zawodowym ${ }^{65}$.

Wśród zadań kapłanów, mających wpływ na kształtowanie wspólnoty, należy wymienić wszelkie działania służące rozmodleniu parafii. Do istotnych akcji duszpasterskich należy zaliczyć m.in. misje święte, rekolekcje w okresie Adwentu czy Wielkiego Postu, dni skupienia dla różnych grup, adoracje Najświętszego

${ }^{63}$ Benedykt XVI, Encyklika Caritas in veritate, Rzym 2009, nr 34.

${ }^{64}$ Franciszek, Adhortacja apostolska Evangelii gaudium..., nr 175.

${ }^{65}$ Por. Benedykt XVI, Przemówienie do biskupów polskich podczas wizyty „ad limina Apostolorum" (Watykan - 26 listopada 2005), Poznań 2005, s. 10. 
Sakramentu, pielgrzymki, szkoły modlitwy prowadzone systematycznie w parafiach. Modlitwa ma doniosły wpływ na relację modlącego się do wspólnoty i bliźnich. Człowiek, stając na modlitwie wobec Boga, dostrzega własne braki, niedociagnięcia i wady, a to z kolei pociąga za sobą możliwość zrozumienia innej osoby i zajęcia wobec niej właściwej postawy. Poprzez modlitwę człowiek może wypraszać dla wspólnoty Kościoła potrzebne łaski. Modlitwa ma być również miejscem, gdzie człowiek siebie i drugich zbliża do źródła miłości, jakim jest Bóg ${ }^{66}$. W ten sposób parafia przyczynia się do duchowego i moralnego wzrostu Ludu Bożego, staje się rzeczywiście wspólnotą kościelną i kościelną rodziną.

Kapłan, szukając wspólnego dobra Kościoła, powinien popierać stowarzyszenia wiernych i ruchy, które stawiają sobie cele religijne, przyjmując je i pomagając im znaleźć łączącą je jedność zamierzeń w modlitwie i działalności apostolskiej. Szczególnie powinien otaczać troską rozwijającą się w Kościele Akcję Katolicką ${ }^{67}$. Jest ona nieodzownym ruchem kościelnym i winna doznawać poparcia od wszystkich, szczególnie jednak od kapłanów. Jej celem jest formacja ludzi świeckich i ich aktywne uczestnictwo w życiu społecznym. To oni powinni przyczyniać się do uspołecznienia wiary. Rozpoczynając 19 czerwca 2009 r. Rok Kapłański, papież Benedykt XVI pisał do kapłanów: „Cieszę się, że mogę skierować do kapłanów [...] szczególną zachętę, aby potrafili pojąć nową wiosnę, którą Duch rozbudza w naszych dniach w Kościele, nie na poślednim miejscu poprzez nowe ruchy kościelne i nowe wspólnoty" ${ }^{16}$. Potrzeba niewątpliwie mądrości i nieustannej modlitwy zarówno samych kapłanów, jak i wspólnot religijnych, aby tę „wiosnę" przyjąć, a nie uciekać przed nią. Potrzeba jednak także pokory, aby ożywiający te wspólnoty Duch był przyjęty przez samych kapłanów oraz powstające wspólnoty w duchu katolickiej służby. Jakże pięknie wyraził to Benedykt XVI podczas spotkania z przedstawicielami ruchów kościelnych na Jasnej Górze: „Sprawdzianem autentyczności waszej wiary i waszej misji, która nie zwraca uwagi na siebie, ale realnie budzi wiarę i miłość, będzie porównanie z wiarą Maryi. Przeglądajcie się w Jej sercu. Bądźcie Jej uczniami!"ø9.

Mówiąc o budowaniu wspólnoty parafialnej, nie można też zapomnieć o zadaniu, jakim jest troska o nowe powołania kapłańskie. Jest rzeczą oczywistą, że Tym, który powołuje, jest Bóg, a troska o nowych kapłanów wpisuje się w całość misji Kościoła ${ }^{70}$. Słowa Chrystusa: „Proście Pana żniwa, żeby wyprawił ro-

${ }^{66}$ Por. Franciszek, Encyklika Lumen fidei..., nr 46.

${ }^{67}$ Por. K. Jeżyna, Udział Akcji Katolickiej w nowej ewangelizacji, w: Akcja katolicka w społeczeństwie polskim, red. R. Podpora, Lublin 1999, s. 44-83.

${ }^{68}$ Benedykt XVI, List na rozpoczęcie Roku Kapłańskiego z okazji 150. rocznicy ,,dies natalis" świętego proboszcza z Ars, Kraków 2009, s. 5.

${ }^{69}$ Benedykt XVI, Przemówienie wygłoszone podczas spotkania z zakonnikami i zakonnicami, z seminarzystami oraz przedstawicielami ruchów kościelnych na Jasnej Górze (Jasna Góra - 26 maja 2006), w: tenże, Trwajcie mocni w wierze. Pielgrzymka do Polski 25-28 maja 2006, Warszawa 2006 , s. 51.

${ }^{70}$ Por. Benedykt XVI, Adhortacja apostolska Sacramentum caritatis..., nr 25. 
botników na swoje żniwo" (Mt 9,38) muszą być słyszane przez wszystkich członków Kościoła. Jednak szczególna rola przypada tu kapłanom pracującym w duszpasterstwie ${ }^{71}$.

Kapłani powinni najpierw wspierać rodziny katolickie w ich wysiłku wychowawczym zgodnym z Ewangelią i wartościami prezentowanymi i głoszonymi przez Kościół. Następnie są zobowiązani podejmować odpowiednią pracę duszpasterską. Ważną rolę w tym względzie odgrywają m.in. organizowane dni modlitw o powołania, rekolekcje zamknięte dla maturzystów, z możliwością spotkania się z klerykami, specjalny rodzaj katechez, ruch oazowy i pielgrzymkowy, stowarzyszenia młodzieżowe i ruchy charyzmatyczne. Okazją służącą promocji powołań kapłańskich są prymicje, śluby osób konsekrowanych, jubileusze kapłańskie i zakonne. W tym wypadku ważna jest ich forma zewnętrzna, którą należy dobrze przygotować, nie gubiąc piękna, sensu i wielkości samego kapłaństwa ${ }^{72}$.

Trzeba jednak stwierdzić, że najważniejszym i niezastapionym, a zarazem najbardziej skutecznym środkiem budzenia powołań kapłańskich jest świadectwo życia kapłanów, ich zdolność do poświęcenia i bezwarunkowego oddania się na służbę Chrystusowi i Jego Kościołowi. Tożsamość i misja spotkanego kapłana to często dla młodego człowieka droga do odkrycia powołującego głosu Chrystusa. Ojciec Święty Benedykt XVI podczas wizyty polskich biskupów ad limina Apostolorum 26 listopada 2005 r. mówił:

Serdecznie proszę was, Bracia, abyście zachęcali kapłanów do troski o dzieci i młodzież, którzy stają przy ołtarzu Pańskim jako ministranci i lektorzy. Niech otaczają duszpasterską opieką także dziewczęta, które również, na sposób im właściwy, czynnie uczestniczą w liturgii. Ta duszpasterska posługa może być owocna w budowaniu powołań kapłańskich i zakonnych ${ }^{73}$.

Nie sposób dotknąć wszystkich obszarów zaangażowania kapłana w dzieło budowania wspólnoty Kościoła parafialnego. Trudno bowiem przewidzieć wciąż nowe wyzwania, szanse, ale i zagrożenia. Podejmując się jednak dzieła budowania wspólnoty parafialnej, każdy kapłan musi być przede wszystkim człowiekiem wiary, miłosiernej miłości i głębokiej duchowości.

Kapłan [...] powinien więc - jak uczy papież Benedykt - zaplanować szeroką formację dla życia duchowego. Jest on wezwany, by autentycznie poszukiwał Boga, będąc równocześnie blisko ludzkich spraw. Intensywne życie duchowe pozwoli mu wejść coraz głębiej w komunię z Panem i pomoże mu dać się posiąść przez miłość Bożą, stając się świadkiem w każdej okoliczności, również trudnej i ciemnej ${ }^{74}$.

${ }^{71}$ Por. A. Kokoszka, Rozpalić kapłański charyzmat..., s. 128-130.

${ }^{72}$ Por. Kaplaństwo i życie konsekrowane..., nr 46-53.

${ }^{73}$ Benedykt XVI, Przemówienie do biskupów polskich podczas wizyty „ad limina Apostolorum”..., s. 29-30.

${ }^{74}$ Benedykt XVI, Adhortacja apostolska Sacramentum caritatis..., $\mathrm{nr} 80$. 
Ośrodkiem życia duchowego i źródłem uświęcenia jest dla kapłanów - jak już zostało wspomniane - godne i pobożne sprawowanie Najświętszego Sakramentu, a także codzienne czytanie Pisma Świętego, lektura duchowna, adoracja, brewiarz odmawiany $\mathrm{z}$ wewnętrznym skupieniem, modlitwa różańcowa i dokładny rachunek sumienia. Warunkiem zaś wytrwania w powołaniu i duchowości kapłańskiej jest nabożeństwo do Matki Najświętszej. „Nikt bowiem tak jak Maryja - przekonuje Ojciec Święty Franciszek - nie poznał głębokości tajemnicy Boga, który stał się człowiekiem"75. Czcząc Maryję, Matkę Zbawiciela, każdy kapłan powinien ukochać ją jako swoją Matkę. Pozwoli mu to przejąć od Niej bogactwo daru miłości służebnej, tak bardzo potrzebnej do realizacji powołania kapłańskiego i kształtowania wspólnoty parafialnej ${ }^{76}$.

Gorliwa modlitwa księdza powinna obejmować wszystkich, do których posyła go Bóg. W modlitwie wyraża się prawdziwa troska duszpasterza o tych, którzy zostali mu powierzeni. Gorliwa, codzienna modlitwa wyznacza także istotny styl życia kapłańskiego. Bez niej, nie ma mowy o świętości ani upodobnieniu się do Chrystusa, niezbędnym, by godnie sprawować in persona Christi święte misteria wiary ${ }^{77}$.

W końcu należy też wskazać, że z kapłaństwem służebnym wiąże się ściśle obowiązek celibatu. Według papieża Benedykta XVI „kapłański celibat przeżyty w sposób dojrzały, z radością i oddaniem jest ogromnym błogosławieństwem dla Kościoła i również dla całego społeczeństwa"78. Trwanie w nim jest sprawdzianem wewnętrznej dojrzałości księdza. Celibat jako całkowity dar swego życia Bogu i ludziom przeżywany prawidłowo i dojrzale staje się najwyższym świadectwem o królestwie Bożym i wyraża postawę dyspozycyjności w Kościele i dla Kościoła ${ }^{79}$.

Tak więc trzeba powiedzieć, że człowiek naprawdę uczy się doktryny społecznej Kościoła tam, gdzie się ją realizuje, gdzie dojrzewają doświadczenia ewangelizacyjne i następuje humanizacja rzeczywistości społecznej. Parafia jako rodzina dzieci Bożych wypełnia swoją misję, gdy przyjmuje człowieka i - po zrodzeniu go do „nowego życia” - sprawia, że człowiek wzrasta. Wspólnota parafialna nie może także zaprzestać poszukiwania rozproszonych, przychodząc im $\mathrm{z}$ pomocą. Stąd też jednym z fundamentalnych celów podejmowanego w parafiach duszpasterstwa jest wychowywanie do praktykowania czynnej miłości mi-

\footnotetext{
${ }^{75}$ Franciszek, Bulla Misericordiae vultus..., nr 24. Por. szerzej: B. Kochaniewicz, Matka Boża w posoborowej liturgii Kościoła, „Salvatoris Mater” 4(2002), nr 1, s. 157-202.

${ }^{76}$ Por. J. Królikowski, K. Kupiec, Święte posłanie. Z teologii kapłaństwa, Tarnów 2005, s. $97-$ $-102$.

${ }^{77}$ Por. J.M. Verlinde, Duchowość kaptańska w nauczaniu Jana Pawła II, tłum. G. Kania, Warszawa 2004, s. 94-96.

${ }^{78}$ Benedykt XVI, Adhortacja apostolska Sacramentum caritatis..., nr 25.

${ }^{79}$ S. Mojek, Jaki jest sens celibatu kapłańskiego?, w: Problemy współczesnego Kościoła, red. M. Rusecki, Lublin 1997, s. 483-492.
} 
łosiernej. Prezbiterzy mają obowiązek formowania chrześcijan, aby ci nie żyli tylko dla siebie, lecz aby - według wymagań nowego prawa miłości - każdy tak, jak otrzymał łaskę, służył nią drugiemu i aby w ten sposób wszyscy po chrześcijańsku wypełnili swoje obowiązki we wspólnocie ludzkiej.

\section{Podsumowanie}

Miłosierdzie, będąc formą miłości bezinteresownej, która ze swej natury pragnie promować życie, przynależy do Boga. Jego miłosierne oblicze w pełni ukazuje Chrystus, włączając wierzących w ten krąg miłosierdzia, w którym sami ubogaceni, mogą świadczyć o miłosierdziu i je czynić. Chrześcijańska duchowość oznacza styl życia naznaczony taką właśnie miłością agape, która, zgodnie z wrażliwością ewangeliczną, najpierw pochyla się nad najbardziej potrzebującymi, a następnie ogarnia wszystkich bez wyjątku.

Na duchowość miłosierdzia składa się cały proces wewnętrzny rozpoczynający się od odkreślonej wiedzy, poprzez wewnętrzną wrażliwość, po konkretny czyn. Trwający rok miłosierdzia, będący okazją do ożywienia u wszystkich wierzących tej istotnej cechy ich powołania, w szczególności powinien „prowokować” kapłanów do pielęgnowania „wyobraźni miłosierdzia” i także w tej dziedzinie stawania się żywym znakiem, prorockim świadectwem dla całego Kościoła i świata.

W życiu kapłańskim nie ma ważniejszej sprawy niż czynna miłość bliźniego, czyli miłosierdzie znajdujące swój wyraz w trosce o różnorakie potrzeby ciała i ducha bliźniego, w trosce mającej na celu osiagnięcie przez niego najwyższego dobra, czyli zbawienia. Praktykowanie autentycznego miłosierdzia - to znaczy miłosierdzia w duchu Chrystusa - urasta więc w życiu kapłańskim do rangi jakby pierwszorzędnego zadania. Stopień zaangażowania się w miłosierdzie stanowi o stopniu zaangażowania się w kapłaństwo.

Siostra Faustyna doszła do wielkiej świętości poprzez całkowite zaangażowanie się w Chrystusowe miłosierdzie wobec ludzi, wyrażające się przede wszystkim w pragnieniu ich zbawienia. To jest również droga dla kapłanów, misjonarzy Bożego miłosierdzia: dążyć do doskonałości, skupiając się na jej istocie, tzn. na miłosierdziu, dążyć do świętości, starając się o czynną miłość bliźniego, która wypływa $\mathrm{z}$ miłości do Boga. Wiąże się to $\mathrm{z}$ troską o to, by wykorzystać wszystkie swoje możliwości oraz możliwości innych, aby doprowadzić jak najwięcej ludzi do uczestniczenia w życiu Boga i w Jego świętości.

W tej perspektywie wydaje się, że miłosierdzie jako styl życia kapłańskiego wymaga, by go ponownie przedstawić z nowym entuzjazmem i z odnowiona działalnością duszpasterska. Jest to kluczowe zadanie dla Kościoła oraz dla wiarygodności jego głoszenia. Chodzi o to, aby kapłan żył i całym sobą świadczył o miłosierdziu. Język kapłana, jego gesty i postawa powinny przekazywać 
miłosierdzie. Dobrze przeżywany sakrament kapłaństwa staje się zaczynem ewangelicznym, który sprawia, że w Kościele uobecnia się wspólnota miłości i braterstwa. Poprzez wierność swojemu powołaniu i świadectwo życia przepełnionego miłością kapłaństwo przyczynia się do wzrostu całego Kościoła i do Jego świętości.

Dokonane studium wskazuje na aktualność zagadnienia w odniesieniu do współczesnego stylu życia kapłańskiego. Kwestia odnalezienia służebnego wymiaru kapłaństwa jest tematem ciagle niewyczerpanym i otwartym. Można więc żywić nadzieję, że przedłożone refleksje staną się swego rodzaju zaproszeniem do bardziej pogłębionego studium omówionych problemów, a przez to ukażą, jak wielkie i ważne zadania stoją wciąż przed współczesnym kapłaństwem jako sakramentem w służbie głoszenia i urzeczywistniania miłosierdzia w Kościele i świecie.

\author{
A Priest as a Servant of Mercy \\ The Moral-Pastoral Refection in the Context \\ of the Extraordinary Jubilee of Mercy (December 8, 2015 - November 20, 2016)
}

\begin{abstract}
The Extraordinary Jubilee of Mercy announced in the bull Misercicordiae vultus by the Holy Father Francis, becomes an opportunity to reflect on the priestly vocation in the context of the truth about mercy. The practice of authentic mercy is a fundamental task of priestly life. In this perspective it seems that the mercy as the style of the priestly life requires to be presented again with new enthusiasm and with renewed pastoral activity. This is a key task for the Church.

Therefore, the moral-pastoral reflections included in this publication aim to - in the light of the documents of the Church, especially the writings and statements of popes: John Paul II, Benedict XVI and Francis - encourage in the Holy Year to rediscover and revive the sense of identity and essential tasks of priestly ministry fulfilled primarily in preaching and practicing the virtue of mercy.
\end{abstract}

\title{
Keywords
}

priesthood, mercy, teaching, service, word of God, sacraments, community

\section{Słowa kluczowe}

kapłaństwo, miłosierdzie, nauczanie, służba, słowo Boże, sakramenty, wspólnota

\section{Bibliografia}

Baniak J., Wierność powołaniu, a kryzys tożsamości kapłańskiej. Studium socjologiczne na przykładzie Kościoła w Polsce, Poznań 2000.

Bartoszek A., Człowiek w obliczu cierpienia i umierania. Moralne aspekty opieki paliatywnej, Katowice 2000. 
Benedykt XVI, Adhortacja apostolska Sacramentum caritatis, Rzym 2007.

Benedykt XVI, Adhortacja apostolska Verbum Domini, Rzym 2010.

Benedykt XVI, Encyklika Caritas in veritate, Rzym 2009.

Benedykt XVI, Encyklika Deus caritas est, Rzym 2005.

Benedykt XVI, List na rozpoczęcie Roku Kapłańskiego z okazji 150. rocznicy „,dies natalis" świętego proboszcza z Ars, Kraków 2009.

Benedykt XVI, Przemówienie do biskupów polskich podczas wizyty „ad limina Apostolorum” (Watykan - 26 listopada 2005), Poznań 2005.

Benedykt XVI, Przemówienie wygłoszone podczas spotkania z zakonnikami i zakonnicami, z seminarzystami oraz przedstawicielami ruchów kościelnych na Jasnej Górze (Jasna Góra - 26 maja 2006), w: tenże, Trwajcie mocni w wierze. Pielgrzymka do Polski 25-28 maja 2006, Warszawa 2006, s. 47-51.

Franciszek, Adhortacja apostolska Evangelii gaudium, Rzym 2013.

Franciszek, Bulla Misericordiae vultus, Rzym 2015.

Franciszek, Encyklika Laudato si', Rzym 2015.

Franciszek, Encyklika Lumen fidei, Rzym 2013.

Jan Paweł II, Adhortacja apostolska Christifideles laici, Rzym 1988.

Jan Paweł II, Adhortacja apostolska Ecclesia in Europa, Rzym 2003.

Jan Paweł II, Adhortacja apostolska Pastores dabo vobis, Rzym 1992.

Jan Paweł II, Adhortacja apostolska Reconciliatio et paenitentia, Rzym 1984.

Jan Paweł II, Dar i tajemnica, Kraków 1996.

Jan Paweł II, Encyklika Dives in misericodia, Rzym 1980.

Jan Paweł II, Encyklika Sollicitudo rei socialis, Rzym 1987.

Jan Paweł II, List do kapłanów na Wielki Czwartek „Kapłaństwo stużebne”, w: Listy Ojca Świętego Jana Pawła II do wszystkich kapłanów Kościoła Na Wielki Czwartek (1979-1997), red. D. Greggio, Kraków 1998, s. 11-34.

Jan Paweł II, Listy Ojca Świętego Jana Pawła II do wszystkich kapłanów Kościoła na Wielki Czwartek (1979-1997), Kraków 1998.

Jeżyna K., Udziat Akcji Katolickiej w nowej ewangelizacji, w: Akcja katolicka w społeczeństwie polskim, red. R. Podpora, Lublin 1999, s. 44-83.

Kijas Z. J., Nowy kapłan na nowe czasy. Rozważania na temat duchowości kapłańskiej, Kraków 2002.

Kochaniewicz B., Matka Boża w posoborowej liturgii Kościoła, „Salvatoris Mater” 4(2002), nr 1, s. 157-202.

Kodeks prawa kanonicznego, Poznań 1984.

Kokoszka A., Rozpalić kapłański charyzmat, w: W trzecie tysiaclecie. Komentarz pastoralny do dokumentów II Polskiego Synodu Plenarnego, red. W. Lechowicz, Tarnów 2002, s. 127-139.

Kongregacja do spraw Duchowieństwa, Dyrektorium o postudze i życiu prezbiterów, Kraków 2013.

Kowalska M.F., Dzienniczek, Warszawa 1993.

Królikowski J., Kupiec K., Święte posłanie. Z teologii kapłaństwa, Tarnów 2005. 
Międzybrodzki J., Duchowość kapłana w nauczaniu Jana Pawła II, Katowice 2007.

Misiurek J., Nauka Soboru Watykańskiego II o prezbiteracie, w: Kapłan pośród ludu kapłańskiego. Homo meditans XIV, red. W. Słomka, J. Misiurek, Lublin 1993, s. 75-86.

Mojek S., Jaki jest sens celibatu kapłańskiego?, w: Problemy wspótczesnego Kościoła, red. M. Rusecki, Lublin 1997, s. 483-492.

Mojek S., Formacja do czynnej mitości mitosiernej $w$ duszpasterstwie parafialnym, „Roczniki Teologiczne” 49(2002), z. 3, s. 115-133.

Mojek S., Preferencyjna mitość do ubogich $w$ duszpasterstwie parafialnym, „Roczniki Teologiczne" 48(2001), z. 3, s. 113-131.

Mojek S., Wolontariat chrześcijański wyrazem czynnej mitości bliźniego, „Roczniki Teologiczne" 47(2000), z. 3, s. 189-207.

Nagórny J., Kapłan - stuga Nowego Przymierza, „Roczniki Teologiczno-Kanoniczne” 1986, z. 3, s. 55-71.

Przygoda W., Postuga charytatywna Kościoła w Polsce. Studium teologiczno-pastoralne, Lublin 2004.

Słomka W., Duchowość kapłańska, Lublin 1996.

Słomka W., Natura i misja stużebnego kaptaństwa, w: Źródlo postaw i życia chrześcijańskiego, red. W. Słomka, Lublin 1996, s. 266-277.

Sobór Watykański II, Dekret o posłudze i życiu kapłanów Presbyterorum ordinis, w: Sobór Watykański II, Konstytucje. Dekrety. Deklaracje, Poznań 2002, s. 487-517.

Sobór Watykański II, Konstytucja dogmatyczna o Kościele Lumen gentium, w: Sobór Watykański II, Konstytucje. Dekrety. Deklaracje, Poznań 2002, s. 105-166.

Sobór Watykański II, Konstytucja duszpasterska o Kościele w świecie współczesnym Gaudium et spes, w: Sobór Watykański II, Konstytucje. Dekrety. Deklaracje, Poznań 2002, s. 537-620.

Sobór Watykański II, Konstytucja o liturgii świętej Sacrosanctum concilium, w: Sobór Watykański II, Konstytucje. Dekrety. Deklaracje, Poznań 2002, s. 40-70.

Verlinde J. M., Duchowość kapłańska w nauczaniu Jana Pawła II, tłum. G. Kania, Warszawa 2004. 